\title{
Job Quality in the Economy for the Common Good: conceptua- lisation and implementation in Austria and Germany
}

\author{
Laia Ollé-Espluga \\ Johanna Muckenhuber \\ Markus Hadler
}

ABSTRACT: The Economy for the Common Good (ECG) is an Austrian-born movement promoting an alternative economic model built on values oriented to the common welfare such as human dignity, solidarity, ecological sustainability, social justice, transparency and democratic participation. To provide (high) quality of work plays an important role in the ECG philosophy but little is known on the actual labour conditions of workers employed in such type of firms and whether they differ from those of firms in the "regular" default economy. In this paper we focus on Austria and Germany, the countries where this economic model is most widespread, and present results on the general structure of firms following the ECG model and the working and employment conditions in these firms. We identify three main dimensions of job quality promoted by the ECG model, namely employment quality, information and worker participation, and psychosocial working conditions. Using data published in the Common Good Reports, we extracted data informing about these dimensions of job quality at an organisational level of 59 firms with at least 5 employees in Austria and Germany. We discuss which work-related features are promoted by organisations following the ECG model and compare them to the standards encouraged by the model. Results are also discussed with respect to evidence on the quality of work in the social economy.

KEYWORDS: Economy for the Common Good, job quality, Austria.

ECONLIT DESCRIPTORS: B55, P49, J81, J82.

How to cite this article: OLLÉ-ESPLUGA, S., MUCKENHUBER, J. \& HADLER, M. (2020): "Job Quality in the Economy for the Common Good: conceptualisation and implementation in Austria and Germany", CIRIEC-España, Revista de Economía Pública, Social y Cooperativa, 99, 177-202. DOI: 107203/CIRIEC-E.99.16080.

Correspondence: Laia Ollé-Espluga, Karl-Franzens University of Graz (Austria) and TecnoCampus Chair in Social Economy and GREDS-EMCONET, Department of Political and Social Sciences, Universitat Pompeu Fabra (Spain), Email: laia.olle-espluga@uni-graz.at, ORCID: orcid.org/0000-0001-8943-6625;

Johanna Muckenhuber, FH-Joanneum - University of Applied Science in Graz (Austria), Email: johanna. muckenhuber@fh-joanneum.at, ORCID: orcid.org/0000-0001-8275-273X;

Markus Hadler, Karl-Franzens University of Graz (Austria) and Macquarie University (Australia). Email: markus.hadler@uni-graz.at. ORCID: orcid.org/0000-0002-0359-5789. 


\section{RESUMEN AMPLIO}

\section{Calidad del trabajo en la Economía del Bien Común: conceptualización e implementación en Austria y Alemania}

La Economía del Bien Común es un movimiento nacido en Austria que promueve un modelo económico alternativo basado en valores dirigidos al bienestar común como la dignidad humana, la solidaridad, la sostenibilidad ecológica, la justicia social, la transparencia y la participación democrática. Proveer (alta) calidad del trabajo desempeña un papel importante en la filosofía de la Economía del Bien Común. Se pueden distinguir tres grandes dimensiones de calidad del trabajo promovidas por el modelo: (1) la voluntad de evitar la discriminación y aumentar la calidad del empleo; (2) el fomento de la información y participación de los trabajadores; y, en lo que respecta a condiciones de trabajo, (3) la promoción de factores psicosociales beneficiosos (por ejemplo, la flexibilidad de los horarios de trabajo, la conciliación de la vida laboral y personal, o la claridad y variedad de las tareas). No obstante, se dispone de escaso conocimiento sobre las condiciones laborales reales de los trabajadores empleados en este tipo de empresas ni sobre si estas difieren de las de las empresas de la economía "ordinaria".

Este trabajo tiene como objetivo describir la estructura general y las condiciones de trabajo y empleo existentes en las empresas que siguen la Economía el Bien Común en Austria y Alemania, los países donde este modelo económico está más extendido. La fuente de información utilizada son los informes del Bien Común de empresas en Austria y Alemania con un mínimo de 5 empleados y vigentes en enero de 2018. En total, 59 empresas cumplían los criterios de inclusión y se extrajeron de sus informes los datos relativos a la calidad del trabajo a nivel organizativo. Se completa la descripción mostrando también los datos relativos al conjunto de la economía austríaca y alemana, a manera de puntos de referencia.

Los resultados del estudio muestran que casi 13.400 trabajadores están empleados en las empresas de la Economía del Bien Común analizadas. Estas empresas son en su mayoría empresas privadas con fines de lucro, de tamaño medio y se concentran en pocas ramas de actividad económica (especialmente en Actividades de salud y trabajo social, Actividades administrativas y de servicios de apoyo, e Industria manufacturera).

En cuanto a las dimensiones de la calidad del trabajo en estas empresas, los resultados muestran que, en relación a las condiciones de empleo (1), el uso de trabajo a tiempo parcial y de contratos de prácticas prevalece más que en el conjunto de la economía austríaca y alemana. En las empresas analizadas, la desigualdad salarial -medida en función de la relación entre el salario mínimo y el 
máximo- oscila entre 1:1 y 1:13. La desigualdad salarial media para el conjunto de las organizaciones estudiadas es de 1:3,8, un valor inferior a lo que se considera una desigualdad alta en los estándares de la Economía del Bien Común (1:5). La oferta de algún tipo de formación continua a la plantilla está muy extendida en las empresas adheridas a la Economía del Bien Común (presente en más del 80\% de las organizaciones analizadas).

En relación a los indicadores referentes a participación e información (2), en más del 80\% de las empresas estudiadas se comunica información crítica a la plantilla mientras que la participación de los trabajadores toma formas diferentes en las empresas que siguen la Economía del Bien Común. El establecimiento de reuniones periódicas con todo el personal -una forma de participación directa- es la práctica participativa más extendida entre las empresas analizadas. La existencia de comités de empresa -un órgano de participación representativa- es menos frecuente que las prácticas de participación directa pero está más presente que en el conjunto de las economías austriaca y alemana. Se ofrecen formas de participación financiera en menos de un $20 \%$ de las empresas analizadas.

Con respecto a los resultados sobre condiciones de trabajo (3), los aspectos recogidos en los Informes del Bien Común se refieren principalmente a la capacidad de los trabajadores de influir en su forma de trabajar. En más de la mitad de las empresas se facilita autonomía para que su plantilla decida cómo organizarse sus tareas y, en menor medida, se proporciona capacidad a la plantilla para decidir sobre su tiempo de trabajo. También, el personal empleado en empresas de la Economía del Bien Común disfruta de la posibilidad de trabajar desde casa en mayor medida que los trabajadores de Austria y Alemania.

Este artículo explora por primera vez las condiciones de trabajo y empleo en las empresas adheridas al modelo de la Economía del Bien Común, a la vez que discute qué aspectos laborales son promocionados en mayor medida en estas empresas en comparación con los estándares fomentados por el modelo. Los resultados sugieren que los elementos de buena calidad del trabajo en las empresas de Economía del Bien Común se concentran más en los ámbitos de la participación de los trabajadores y del control de horarios y tareas laborales que en los aspectos pecuniarios de la calidad del empleo. En general, los resultados del estudio muestran similitudes con los rasgos de calidad del trabajo más presentes en la economía social. Dado que la Economía del Bien Común constituye un modelo económico alternativo en auge del que todavía hay un conocimiento científico limitado, una de las principales contribuciones del estudio es que ofrece datos originales y necesarios para cubrir lagunas de conocimiento sobre la calidad del trabajo en la economía social y particularmente en la Economía del Bien Común.

En cuanto a las limitaciones del estudio, el uso de los informes del Bien Común como fuente de información ha condicionado el análisis de la calidad del trabajo realizado en este estudio. Esto se debe a la variabilidad en la amplitud y profundidad de la información recogida en estos informes y a que ofrecen una caracterización de la calidad del trabajo desde la perspectiva organizacional, sin 
inclusión de la perspectiva de sus trabajadores. Además, a pesar de que el estudio tiene un carácter descriptivo y de que los datos de la economía austríaca y alemana en su conjunto se proporcionan a manera de referencia, hay que tener en cuenta algunas cuestiones de comparabilidad relacionadas con la formulación de las preguntas o las poblaciones de estudio de referencia. No obstante, el uso de informes del Bien Común como fuente de información y la comparación de la información presente en estos informes con la situación en empresas de la economía "ordinaria" también ha permitido poner de manifiesto el alto grado de transparencia de las empresas del Bien Común, y de la economía social en general, a la hora de comunicar información de carácter no financiero.

PALABRAS CLAVE: Economía del Bien Común, calidad del trabajo, Austria, Alemania. 


\section{Introduction}

Launched in 2010, the Economy for the Common Good (ECG) stands out as an Austrian-born movement pursuing a cooperative, non-capitalist market economy (Felber, 2012: 66). Its main objective is "that the economy must serve people; in other words, the common good" (European Economic and Social Committee, 2015, p. C13/C28) and to do so it promotes an alternative economic model built on values oriented to the common welfare such as human dignity, solidarity, ecological sustainability, social justice, transparency, and democratic participation (Felber, 2012). Since then, the ECG movement has spread around the world: it is estimated that over 2000 organisations support the ECG model, and that some 400 of them have assumed a more active commitment by becoming members of the Association for the Promotion of the ECG or having produced a Common Good Balance Sheet (Economy for the Common Good, 2019).

Firms' contribution to the advancement of the common good is measured on the basis of their impact on different stakeholders. Employees in firms adhering to the ECG values are one of the stakeholders the model is directed to. In this sense, one of the main components promoted by the ECG with respect to workers is the promotion of high quality of work. However, given the novelty of this economic model, there is only scarce knowledge on the actual labour conditions of workers employed in such firms.

Thus, the aim of this paper is to describe the quality of jobs in companies following the ECG model in Austria and Germany and to provide information on similar indicators for the overall Austrian and German economy as a benchmark. This paper is organised as follows: first, we introduce the goals, values and tools of ECG. We draw attention to the standards it encourages regarding employment and working conditions. In the methods section, we account for the data sources used in our descriptive analyses. We then present our main results regarding the structure of ECG firms and different dimensions of job quality in Austria and Germany and, whenever similar information is available, show the corresponding numbers for the overall economy of Austria and Germany. We conclude with a discussion of the contribution of our findings to shed light on the actual working and employment conditions of ECG employees.

\section{Economy for the Common Good}

The ECG promotes an economic system striving for an ethics-based, liberal, redesigned market economy. Ethics-based because in this model the accomplishment of firms is not assessed primarily 
in economic terms such as profits, but rather according to their contribution to society. Liberal because it will seek to ensure equal opportunities and rights for all market players, and redesigned as it aims that basic needs are not only satisfied through the market, but also through alternative initiatives and economic models (e.g. local collaboration networks, peer-to-peer production, or the commons, among others) (Felber \& Hagelberg, 2017: 19). As a matter of fact, ECG is not a self-centred model: firms can take different legal forms and be combined with other schemes. In sum, the motivation of economic competition is replaced by cooperation so that the collective interest and common good is put above companies' profits. Given ECG's pro-social principles, it has been identified as an emerging model framed within the broad umbrella concept of social economy (Chaves \& Monzón, 2018).

The ultimate goal of the ECG movement is to change the system of values at the business and political level (Stumpf \& Sommer, 2019). Although it is businesses that take the lead in adopting and promoting this alternative economic system, the ECG also envisages a process of political transformation (Gómez Calvo \& Gómez-Álvarez Díaz, 2016: 280). The idea is that countries would alter their institutional framework ${ }^{1}$ by bolstering those firms and organisations most aligned with the ECG values (Chaves \& Monzón, 2018), for instance, via tax and legal advantages. In order to make an objective measurement of firms' contributions to the advancement of the common good, the ECG movement has operationalised different - and evolving - tools such as the Common Good Matrix, the Common Good Reports, and the Common Good Balance Sheets (which is the combination of a Common Good Report and the external audit or a peer evaluation).

The Common Good Matrix is a matrix with 20 topics in which columns refer to the values of the ECG and rows to different stakeholders, namely suppliers, owners, employees, customers, and the social environment (see Figure 1). The evaluation of firms' activities covers positive aspects (i.e. the goal a firm is expected to follow) and negative aspects (what a firm should not do). The maximum score is 1,000 points and the minimum -3,600 points (Economy for the Common Good, 2017). The Common Good Balance sheets summarise the results of the Common Good Matrix while the Common Good Reports explain and develop how an organisation has put into action the ECG values and highlight those aspects that need to be improved (Felber \& Hagelberg, 2017). As well as other reporting schemes existing in the social economy (Salathé-Beaulieu et al., 2019), ECG Balance sheets are a tool of social accounting and impact measurement allowing for transparency and the visibility of the positive social and environmental consequences generated by the activity of such businesses. These reports are available publicly, which distinguishes ECG firms from the default economy, in which company actions remain intransparent.

1.- In a similar vein and at a European level, the Economic and Social Committee approved in 2015 an opinion commending the ECG to be included both in the European Union's and its member-state's legal frameworks (European Economic and Social Committee 2015). 
Figure 1. Common Good Matrix, version 5.0

\begin{tabular}{|c|c|c|c|c|}
\hline $\begin{array}{r}\text { VALUE } \\
\text { STAKEHOLDER }\end{array}$ & Human dignity & $\begin{array}{c}\text { Solidarity and social } \\
\text { justice }\end{array}$ & $\begin{array}{l}\text { Environmental } \\
\text { sustainability }\end{array}$ & $\begin{array}{l}\text { Transparency and } \\
\text { co-determination }\end{array}$ \\
\hline 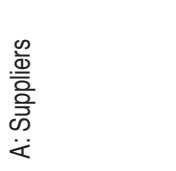 & $\begin{array}{l}\text { A1 Human dignity in } \\
\text { the supply chain }\end{array}$ & $\begin{array}{c}\text { A2 Solidarity and social } \\
\text { justice in the supply } \\
\text { chain }\end{array}$ & $\begin{array}{l}\text { A3 Environmental } \\
\text { sustainability in the } \\
\text { supply chain }\end{array}$ & $\begin{array}{l}\text { A4 Transparency and } \\
\text { co-determination in the } \\
\text { supply chain }\end{array}$ \\
\hline 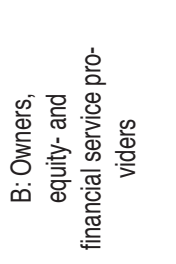 & $\begin{array}{l}\text { B1 Ethical position in } \\
\text { relation to financial } \\
\text { resources }\end{array}$ & $\begin{array}{l}\text { B2 Social position in } \\
\text { relation to financial } \\
\text { resources }\end{array}$ & $\begin{array}{l}\text { B3 Use of funds in } \\
\text { relation to social and } \\
\text { environmental impacts }\end{array}$ & $\begin{array}{l}\text { B4 Ownership and } \\
\text { co-determination }\end{array}$ \\
\hline 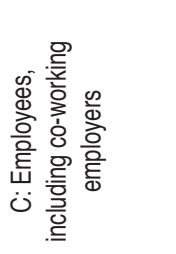 & $\begin{array}{l}\text { C1 Human dignity in } \\
\text { the workplace and } \\
\text { working environment }\end{array}$ & $\begin{array}{l}\text { C2 Self-determined } \\
\text { working arrangements }\end{array}$ & $\begin{array}{l}\text { C3 Environmentally } \\
\text { friendly behaviour of } \\
\text { staff }\end{array}$ & $\begin{array}{l}\text { C4 Co-determination } \\
\text { and transparency within } \\
\text { the organisation }\end{array}$ \\
\hline 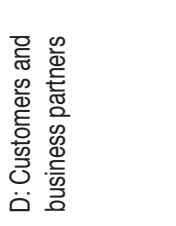 & $\begin{array}{l}\text { D1 Ethical customer } \\
\text { relations }\end{array}$ & $\begin{array}{l}\text { D2 Cooperation and } \\
\text { solidarity with other } \\
\text { companies }\end{array}$ & $\begin{array}{l}\text { D3 Impact on the } \\
\text { environment of the use } \\
\text { and siposal of products } \\
\text { and services }\end{array}$ & $\begin{array}{l}\text { D4 Customer partic- } \\
\text { ipation and product } \\
\text { transparency }\end{array}$ \\
\hline 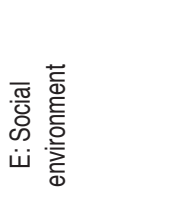 & $\begin{array}{l}\text { E1 Purpose of prod- } \\
\text { ucts and services and } \\
\text { their effects on society }\end{array}$ & $\begin{array}{l}\text { E2 Contribution to the } \\
\text { community }\end{array}$ & $\begin{array}{l}\text { E3 Reduction of envi- } \\
\text { ronmental impact }\end{array}$ & $\begin{array}{l}\text { E4 Social co-determina- } \\
\text { tion and transparency }\end{array}$ \\
\hline
\end{tabular}

SOURCE: (Economy for the Common Good, 2017). 
To date, there are several theoretical studies published on features characterising the ECG (Gómez Calvo \& Gómez-Álvarez Díaz, 2016; Gómez-Álvarez Díaz et al., 2017; Sanchis \& Campos, 2018) and one study performing an empirical validation of the measurement scales used in the Common Good Balance sheets (Felber et al., 2019). However, there is still very limited empirical knowledge of how the ECG model is put into action. Through qualitative analyses or case studies, some researches have focused on the production and management practices in a selection of businesses (Stumpf \& Sommer, 2019), or the case of some particular business model that stands out due to its innovative and sustainable practices (Muller-Camen \& Camen, 2018). Another study described, based on a survey, the profile of European companies following the ECG and analysed the impact of having produced a Common Good Balance sheet (Sanchis, Campos, \& Ejarque, 2019). Based on these data, a descriptive analysis for the Spanish case is provided in Campos, Sanchis \& Ejarque (2019). One ongoing project analyses communication, negotiation and knowledge processes concerning the ECG concept (Kühn, 2020). We draw attention in our study at job quality in firms adhering to this economic model in Austria and Germany with the objective to analyse the distance (or lack of) between the work-related standards encouraged by the ECG and their actual working and employment conditions.

\section{Job quality in the Economy for the Common Good}

Employees represent one group of stakeholders affected by the implementation of the ECG values. Apart from aspects referred to environmental sustainability ${ }^{2}$, ECG's work-related values strive for high job quality. Job quality is a multidimensional concept analysing to what extent the combination of working and employment conditions promote positive outcomes for workers, especially in terms of health outcomes and job satisfaction (Holman, 2013: 476). The most repeated dimensions of job quality identified by a review of the existing literature involve: pay and other rewards; terms of employment and job security; intrinsic characteristics of work (involving either objective characteristics such as autonomy or control, and subjective such as social support or meaningfulness); health and safety; work-life balance; and representation and voice (Warhurst, Wright, \& Lyonette, 2017). In practice, there exist several ways to study job quality, for instance subjective or objective approaches to job quality (Warhurst et al., 2017), or, depending on the proximity to the properties of the job itself, the micro or individualistic level perspective, the meso-level perspective (i.e. including job features or characteristics of the context of the job), or the macro-level perspective (i.e. encompassing macro-level factors affecting job quality such as social protection models or the labour market situation) (Burchell, Sehnbruch, Piasna, \& Agloni, 2014).

2.- In this research, work-related values are understood as those exclusively focused on labour issues thus excluding from our analysis the dimension referred to ecological sustainability 
In the case of the ECG, the model is committed to job security and quality in a way that it relates to, among other Sustainable Development Goals, the objective of "decent work and economic growth". The main points of the ECG's work-related values can be apprehended through the material reported on the ECG workbooks (Blachfellner et al., 2017; Economy for the Common Good, 2015). In Table 1 we depict the work-related standards promoted by the ECG. They can be summarised in three main areas: the willingness to elude discrimination and boost quality of employment -with a strong emphasis on salaries, and to a lesser extent on contract types ${ }^{3}$; the encouragement of information and worker participation; and, regarding working conditions, the promotion of beneficial psychosocial factors at work including among others, flexible work hours, work-life balance, task clarity and variety of tasks, scope and autonomy.

\section{Table 1. Work-related standards promoted by the Economy for the Common Good (ECG) model}

\begin{tabular}{|c|c|}
\hline Key values & Implementation of the work-related standards \\
\hline $\begin{array}{l}\text { Human dignity in the workplace } \\
\text { and working environment (cor- } \\
\text { responding to cell C1 in the } \\
\text { Common Good matrix version } \\
\text { 5) }\end{array}$ & $\begin{array}{l}\text { Human dignity takes place through employee-oriented organisational culture and struc- } \\
\text { tures; occupational safety and workplace health promotion; and diversity (Blachfellner et } \\
\text { al., 2017: 38-40). The former calls for labour management practices that foster beneficial } \\
\text { psychosocial exposures such as respect and constructive handling of conflict; personal } \\
\text { development (by creating meaningful work and assigning tasks on the basis of workers' } \\
\text { talents and strengths); and task clarity. Activities related to occupational health and safety } \\
\text { refer to assuring occupational health and safety (placing special attention in the areas of } \\
\text { ergonomics, work environment and prevention of occupational accidents), offering work- } \\
\text { place health promotion activities for employees but also for managers, and facilitating } \\
\text { that workers with medical conditions can stay at work. As for diversity, the ECG model } \\
\text { pursues to fight segregation and labour discrimination on grounds such as sex, ethnic } \\
\text { origin or disability. It takes into account aspects such as equal opportunities in the hiring } \\
\text { process and for career advancement. }\end{array}$ \\
\hline $\begin{array}{l}\text { Self-determined working ar- } \\
\text { rangements (corresponding to } \\
\text { cell C2 in the Common Good } \\
\text { matrix version 5) }\end{array}$ & $\begin{array}{l}\text { It consists of two main elements: work hours and earnings, and, to a lower extent, con- } \\
\text { tract types (Blachfellner et al., 2017: 41-43). Regarding work hours, the ECG advocates } \\
\text { for the reduction of normal working time (promoting a maximum working week of } 30 \\
\text { hours if approved by all employees), self-determination over working time schedules, } \\
\text { and availability of flexible working arrangements. With respect to earnings, "living wages" } \\
\text { (wages which are in line with the local cost of living) are promoted, as well as the reduc- } \\
\text { tion of income inequality according to job post. Income inequality is diminished through } \\
\text { the establishment of a ratio difference of the highest paid position and the lowest paid. In } \\
\text { experienced firms, the maximum spread is set in 1:5. Regarding contract types, the ECG } \\
\text { model contemplates as a negative aspect the existence of unfair employment contracts. } \\
\text { An employment contract is considered unfair when it is detrimental to the worker, singling } \\
\text { out the example of verbal contracts. }\end{array}$ \\
\hline
\end{tabular}

3.- Two different versions of the Common Good Matrix have been in force in the analysis period included in this study: v.4.1 from 2013 to 2017, and since then v.5. The criteria concerning work-related characteristics have slightly changed between the two versions, giving less weight in $v .5$ to aspects related to the type of contract and part-time employment.

CIRIEC-España, Revista de Economía Pública, Social y Cooperativa ISSN: 0213-8093

$N^{\circ} 99 / 2020$, pp. $177-202$ 


\begin{tabular}{|l|l|}
\hline $\begin{array}{l}\text { Co-determination and trans- } \\
\text { parency within the organisation } \\
\text { (corresponding to cell C4 in the } \\
\text { Common Good matrix version } \\
\text { 5) }\end{array}$ & $\begin{array}{l}\text { Promotion of transparency about critical data, participation in the selection of managers, } \\
\text { and the advancement of workers' direct participation (encouraging that workers get to } \\
\text { decide on essential firms' decisions by democratic or consensual means) are elements to } \\
\text { be put into action in firms adopting the ECG. By contrast, the impediment of works coun- } \\
\text { cils - a scheme of worker representative participation- is judged as a negative criterion. In } \\
\text { case of lack of works council, equivalent rights of co-determination should be facilitated } \\
\text { to workers (Blachfellner et al., 2017: 48-49). }\end{array}$ \\
\hline $\begin{array}{l}\text { Ownership and co-determina- } \\
\text { tion (corresponding to cell B4 } \\
\text { in the Common Good matrix } \\
\text { version 5) }\end{array}$ & $\begin{array}{l}\text { As far as employees are concerned, the model favours employee co-ownership, which } \\
\text { can be put into practice either as financial participation (employees taking part in prof- } \\
\text { its and enterprise results) or as the conformation of worker cooperatives (Blachfellner } \\
\text { et al., 2017: 36-37). However, it should be noted that the ECG model does not only } \\
\text { take workers into account when promoting ownership and co-determination, but also the } \\
\text { whole community where this economic system is located (this is, also considering clients, } \\
\text { suppliers or non-active capital investors among others). }\end{array}$ \\
\hline
\end{tabular}

\section{Methods}

The main question we explore in the present article is to what extent the work-related characteristics of firms following the ECG principles in Austria and Germany are aligned with those proposed by the ECG model. We focus on Austria and Germany, as the ECG movement started in these two countries and is currently the most widespread, and on organisations with at least five employees, coinciding with the minimum of workers set by law for workplaces to set up a body of collective representation in Austria and Germany. We analyse data about structural characteristics of ECG firms and about their job quality derived from ECG sources such as the website of the European Association for the Promotion of the Common Good. We also present data relating to the situation in the Austrian and German economies based on sources such as Eurostat to be used as a reference.

\section{Study population, data sources, and analysis}

As for the firms following the ECG principles in Austria and Germany, we consider all companies fulfilling the following selection criteria: 1) being members of their local ECG association; 2) undertaking more objective Common Good Balances, namely peer-evaluated (performed with the participation of other ECG firms) or externally audited (checked by an ECG auditor); 3) with at least five employees; and 4) with Common Good Balances in force as of January 2018. In order to identify those businesses 
fulfilling the project's selection criteria we first used the information provided in the list of firms with Common Good Balances disclosed by the ECG4. 59 firms matched these criteria and were included in the analyses, with the majority (63\%) located in Germany. The smallest firm in this study provided employment to five employees whereas the largest, to 3,200.

The information on the ECG firms is based on used data published in the Common Good Reports available on the ECG website (Gemeinwohl Ökonomie, 2018). As Common Good evaluations have a validity of two years, the information compiled in the Common Good Reports analysed in this study refers to different years -between 2013 and 2017-, but most frequently to 2015.

With respect to data sources informing about job quality indicators in the Austrian and German economy as a whole, we used different databases from the statistical office of the European Union (Eurostat); from the Organisation for Economic Co-operation and Development (OECD); data informing about wage inequality extracted from the International Labour Office's Global Wage Report 2016/2017 (International Labour Office, 2016); and data from the 3rd European Company Survey (ECS), a survey promoted by the European Foundation for the Improvement of Living and Working Conditions (EUROFOUND) targeted at management representatives (and when possible, also at worker representatives) in various European countries (Eurofound, 2015).

A descriptive analysis was performed through univariate analyses to describe each of the variables reporting about job quality in ECG firms and the overall Austrian and German economy. Table 2 provides an overview of all considered characteristics. Despite the existence of guidelines to create Common Good Reports, we found a large variation regarding the content and details provided by firms. We thus decided to provide the total and valid percentages for each indicator in the case of ECG firms. 


\section{Table 2. Study dimensions and variables analysed}

\begin{tabular}{|c|c|}
\hline Dimension & Indicators \\
\hline $\begin{array}{l}\text { General structure of } \\
\text { firms }\end{array}$ & $\begin{array}{l}\text { - Distribution of firms according to size } \\
\text { - Distribution of firms according to economic sector } \\
\text { - Share of female employees } \\
\text { - Distribution of employees according to economic activity branches (NACE codes) }\end{array}$ \\
\hline Employment quality & $\begin{array}{l}\text { - Type of contract } \\
\text { Firms reporting to employ apprentices } \\
\text { Firms reporting to employ agency workers } \\
\text { - Part-time employment } \\
\text { Share of employees in part-time employment } \\
\text { - Salaries } \\
\text { Firms reporting to provide salaries equal or higher than "living wages" } \\
\text { Wage spread ratio } \\
\text { - Non-wage benefits } \\
\text { Employer-provided benefits (other than Christmas and summer extra pays) } \\
\text { - Training } \\
\text { Firms reporting to provide training } \\
\text { - Possibility for time compensation in case of overtime } \\
\text { Firms reporting time compensation }\end{array}$ \\
\hline $\begin{array}{l}\text { Information and worker } \\
\text { participation }\end{array}$ & $\begin{array}{l}\text { - Critical information shared with employees } \\
\text { Firms reporting to provide critical information } \\
\text { - Leadership legitimacy } \\
\text { Firms reporting processes of democratic election of managers by all or part of the employees } \\
\text { - Direct participation } \\
\text { Firms reporting regular meetings between employees and immediate manager } \\
\text { Firms reporting regular staff meetings open to all employees at the establishment } \\
\text { Firms reporting to undertake employee surveys among employees } \\
\text { - Representative participation } \\
\text { Firms reporting works councils } \\
\text { - Worker participation in health and safety } \\
\text { Firms reporting worker representation in health and safety } \\
\text { - Co-ownership } \\
\text { Firms reporting that employees are shareholders }\end{array}$ \\
\hline $\begin{array}{l}\text { Psychosocial condi- } \\
\text { tions: home office and } \\
\text { control }\end{array}$ & $\begin{array}{l}\text { - Possibility of home office } \\
\text { Share of workers with the possibility of home office } \\
\text { - Control } \\
\text { Firms in which employees have control over their daily working time } \\
\text { Firms in which employees can decide on the planning and execution of their daily work tasks }\end{array}$ \\
\hline
\end{tabular}




\section{Results}

Table 3 offers an overview of different structural characteristics of our ECG firms. The 59 companies included in our study employ almost 13,400 workers. Women represent at least almost half of the workforce in ECG firms; if taking the valid frequency, they account for two thirds of total workforce. Compared to the overall Austrian and German economies, and, whether taking into account total or valid frequencies, ECG firms stand out for being to a higher extent medium sized firms (from 50 to 249 workers) and for being concentrated in fewer economic branches (Human health and social work activities, Administrative and support service activities, and Manufacturing). About two thirds of the ECG firms analysed belong to the private for-profit sector.

\section{Table 3. Structure of Economy for the Common Good (ECG) firms and the totality of firms in Austria and Germany}

\begin{tabular}{|c|c|c|c|}
\hline \multirow[b]{2}{*}{ Company size } & \multicolumn{2}{|c|}{$\begin{array}{l}\text { Economy for the Common Good } \\
\text { firms }\end{array}$} & \multirow{2}{*}{$\begin{array}{c}\text { Firms in Austria } \\
\text { and Germany }\end{array}$} \\
\hline & Total \% & Valid \% & \\
\hline $0-9$ workers* & $18.6 \%$ & $18.6 \%$ & $83.0 \%$ \\
\hline 10-19 workers & $13.6 \%$ & $13.6 \%$ & $9.5 \%$ \\
\hline 20-49 workers & $22.0 \%$ & $22.0 \%$ & $4.7 \%$ \\
\hline 50-249 workers & $28.8 \%$ & $28.8 \%$ & $2.3 \%$ \\
\hline 250 workers or more & $16.9 \%$ & $16.9 \%$ & $0.5 \%$ \\
\hline Total & $\begin{array}{r}100 \% \\
(\text { firms' } n=59)\end{array}$ & $\begin{array}{r}100 \% \\
(\text { firms' } n=59 \text { ) }\end{array}$ & $100 \%$ \\
\hline Economic sector of the company & Total \% & Valid \% & $\%$ \\
\hline Private for profit & $64.4 \%$ & $66.7 \%$ & Not available \\
\hline Non-profit & $22.0 \%$ & $22.8 \%$ & Not available \\
\hline Public & $10.2 \%$ & $10.5 \%$ & Not available \\
\hline Without information & $3.4 \%$ & .. & Not available \\
\hline Total & $\begin{array}{r}100.0 \% \\
(\text { firms' } n=59)\end{array}$ & $\begin{array}{r}100 \% \\
(\text { firms' } n=57)\end{array}$ & \\
\hline
\end{tabular}




\begin{tabular}{|c|c|c|c|}
\hline Female employees & Total \% & Valid \% & $\%{ }^{\mathrm{a} 2}$ \\
\hline$\%$ of female employees & $\begin{array}{r}47.4 \% \\
\text { (employees' } \\
n=13,396 \text { ) }\end{array}$ & $\begin{array}{r}67.2 \% \\
\text { (employees' } \\
n=9,440)^{1}\end{array}$ & $48.1 \%$ \\
\hline $\begin{array}{l}\text { Employees according to economic activity branches (NACE } \\
\text { codes) }\end{array}$ & Total \% & Valid \% & $\%{ }^{b 1}$ \\
\hline Agriculture, forestry and fishing & $1.6 \%$ & $1.6 \%$ & $0.9 \%$ \\
\hline Mining and quarrying & $0.0 \%$ & $0.0 \%$ & $0.1 \%$ \\
\hline Manufacturing & $10.7 \%$ & $10.7 \%$ & $18.3 \%$ \\
\hline Electricity, gas, steam and air conditioning supply & $0.1 \%$ & $0.1 \%$ & $0.6 \%$ \\
\hline $\begin{array}{l}\text { Water supply; sewerage, waste management and } \\
\text { remediation activities }\end{array}$ & $0.0 \%$ & $0.0 \%$ & \\
\hline Construction & $1.1 \%$ & $1.1 \%$ & $5.2 \%$ \\
\hline $\begin{array}{l}\text { Wholesale and retail trade, repair of motor vehicles and } \\
\text { motorcycles }\end{array}$ & $6.6 \%$ & $6.6 \%$ & $13.7 \%$ \\
\hline Transportation and storage & $0.0 \%$ & $0.0 \%$ & $5.2 \%$ \\
\hline Accommodation and food service activities & $2.1 \%$ & $2.1 \%$ & $4.3 \%$ \\
\hline Information and communication & $0.1 \%$ & $0.1 \%$ & $2.8 \%$ \\
\hline Financial and insurance activities & $4.5 \%$ & $4.5 \%$ & $2.7 \%$ \\
\hline Real estate activities & $0.0 \%$ & $0.0 \%$ & $1.1 \%$ \\
\hline Professional, scientific and technical activities & $0.0 \%$ & $0.0 \%$ & $5.4 \%$ \\
\hline Administrative and support service & $24.0 \%$ & $24.0 \%$ & $7.3 \%$ \\
\hline $\begin{array}{l}\text { Public administration and defence; compulsory social } \\
\text { security }\end{array}$ & & & $6.6 \%$ \\
\hline Education & $8.2 \%$ & $8.2 \%$ & $5.9 \%$ \\
\hline Human health and social work activities & $38.0 \%$ & $38.0 \%$ & $13.2 \%$ \\
\hline Arts, entertainment and recreation & $0.3 \%$ & $0.3 \%$ & $1.2 \%$ \\
\hline Other service activities & $2.1 \%$ & $2.1 \%$ & $3.0 \%$ \\
\hline $\begin{array}{l}\text { Activities of households as employers; undifferentiated } \\
\text { activities of households for own use }\end{array}$ & $0.0 \%$ & $0.0 \%$ & $2.0 \%$ \\
\hline Activities of extraterritorial organizations and bodies & $0.0 \%$ & $0.0 \%$ & $0.0 \%$ \\
\hline Total & $\begin{array}{r}100 \% \\
\text { (employees' } \\
n=13,396 \text { ) }\end{array}$ & $\begin{array}{r}100 \% \\
\text { (employees' } \\
n=13,396 \text { ) }\end{array}$ & $100 \%$ \\
\hline
\end{tabular}

Missing information: 1) based on information from 54 firms.

Marked in bold: Information highlighted in the description of results. 
*In ECG firms, analyses have been limited to firms with at least five workers. As for all firms, the smallest available category is "0-9 workers". A large number (around $60 \%$ in Austria) of the "0-9 workers" group are sole proprietors without employees. The $83 \%$ thus can be split roughly in $51 \%$ no employee and $32 \%$ up to 9 employees. Ignoring sole proprietors still shows that ECG firms are more often larger companies in comparison to the totality of firms.

DATA SOURCES: Information about ECG firms has been extracted from Common Good Reports. Latest available years. Information regarding firms in Austria and Germany has been obtained from: a1) year 2015, Eurostat [sbs_sc_sca_r2] (Eurostat, 2018a), a2) $4^{\text {th }}$ quarter of 2015, Eurostat [lfsq_eegais] (Eurostat, 2019b), and b1) year 2016, Organisation for Economic

Co-operation and Development (OECD) [STAN Industrial Analysis] (OECD, 2018b).

On the topic of job quality, information regarding employment quality is presented in Table 4. In the case of Austria's and Germany's economy as a whole, their most positive employment features refer to moderate use of part-time employment (22\%), as well as to a very widespread time compensation in case of overtime and provision of training (with $93 \%$ and $83 \%$, respectively). Training and -to a lower extent- time compensation in the event of overtime also stand out as prevalent favourable employment conditions among firms adhering to the ECG values. On the topic of contract security, it should be noted that insufficient information is provided in the Common Good Reports regarding fixed-term contracts. Yet, the use of part-time work and apprenticeships is more widespread in ECG firms than that of agency workers (both in total and valid \%). The earning spread ratio between the minimum and maximum salaries ranges in ECG firms between $1: 1$ and $1: 13$ and a high wage spread -over 1:5- is present in six firms. The mean of this ratio is 3.8 in ECG firms and 3.4 for default companies in Austria and Germany. In almost half of the ECG firms (69\% of valid responses) full-time salaries are higher than or equal to the reference value for "living wages" in Austria and Germany $(1,330 €$ monthly net income). Among firms not fulfilling "living wages" or without information, salaries are higher than or equal to the official minimum wages in $30 \%$, and in compliance with collective agreements in $13 \%$ (data not shown in Table 4). Apart from salaries, non-wage benefits are offered in 48 out of the 59 analysed organisations, the most frequent being free or reduced-price food. 


\section{Table 4. Job quality in Economy for the Common Good (ECG) firms compared to the totality of firms in Austria and Germany: contract type, earnings, and training}

\begin{tabular}{|c|c|c|c|}
\hline & \multicolumn{2}{|c|}{$\begin{array}{l}\text { Economy for the Common Good } \\
\text { firms }\end{array}$} & \multirow{2}{*}{$\begin{array}{l}\text { Firms in Austria and } \\
\text { Germany } \\
\%^{\mathrm{a} 3}\end{array}$} \\
\hline Type of contract & Total \% & Valid \% & \\
\hline $\begin{array}{l}\text { Firms reporting to employ } \\
\text { apprentices ₹ }\end{array}$ & $\begin{array}{r}61.0 \% \\
\text { (firms' } n=59)\end{array}$ & $\begin{array}{r}94.7 \% \\
(\text { firms' } n=38)\end{array}$ & $54.1 \%$ \\
\hline $\begin{array}{l}\text { Firms reporting to employ } \\
\text { agency workers } \neq\end{array}$ & $\begin{array}{r}13.6 \% \\
(\text { firms' } n=59)\end{array}$ & $\begin{array}{r}18.6 \% \\
(\text { firms' } n=43)\end{array}$ & Not available \\
\hline Part-time employment & Total \% & Valid \% & $\%(2015)^{b 2}$ \\
\hline$\%$ of employees in part-time employment & $\begin{array}{r}36.5 \% \\
\text { (employees' } \\
n=13,396)\end{array}$ & $\begin{array}{r}50.0 \% \\
\text { (employees' } \\
n=9,764)^{1}\end{array}$ & $21.7 \%$ \\
\hline Salaries & Total \% & Valid \% & $\%$ \\
\hline $\begin{array}{l}\text { Firms reporting to provide salaries equal or higher } \\
\text { than "living wages" ( } 1,330 € \text { monthly net income) }\end{array}$ & $\begin{array}{r}49.2 \% \\
(\text { firms' } n=59)\end{array}$ & $\begin{array}{r}69.0 \% \\
(\text { firms' } n=29)\end{array}$ & Not available \\
\hline $\begin{array}{l}\text { Wage spread ratio (distance between the highest and } \\
\text { lowest full-time equivalent salary) }\end{array}$ & \multicolumn{2}{|c|}{$3.8^{2}$} & $3.4^{c}$ \\
\hline $\begin{array}{l}\text { Non-wage benefits } \\
\text { ( } 5 \text { most frequent employer-provided benefits other } \\
\text { than Christmas and summer extra pays) } \neq\end{array}$ & $\begin{array}{r}\text { Total \% } \\
\text { (multiple answer, } \\
\text { computed over } \\
\text { total firms) }\end{array}$ & $\begin{array}{r}\text { Valid \% } \\
\text { (multiple answer, } \\
\text { computed over } \\
\text { firms reporting } \\
\text { information) }\end{array}$ & $\%$ \\
\hline Free or reduced-price food & $\begin{array}{r}32.2 \% \\
\text { (firms' } n=59)\end{array}$ & $\begin{array}{r}39.6 \% \\
(\text { firms' } n=48)\end{array}$ & Not available \\
\hline $\begin{array}{l}\text { Subsidies for private pension provisions or } \\
\text { participation in the company pension scheme }\end{array}$ & $\begin{array}{r}22.0 \% \\
\text { (firms' } n=59 \text { ) }\end{array}$ & $\begin{array}{r}27.1 \% \\
(\text { firms' } n=48)\end{array}$ & Not available \\
\hline $\begin{array}{l}\text { Discounts on leisure activities } \\
\text { or on purchase of articles }\end{array}$ & $\begin{array}{r}18.6 \% \\
\text { (firms' } n=59)\end{array}$ & $\begin{array}{r}22.9 \% \\
\text { (firms' } n=48 \text { ) }\end{array}$ & Not available \\
\hline $\begin{array}{l}\text { Special conditions for in-house } \\
\text { products }\end{array}$ & $\begin{array}{r}13.6 \% \\
(\text { firms' } n=59)\end{array}$ & $\begin{array}{r}16.7 \% \\
(\text { firms' } n=48)\end{array}$ & Not available \\
\hline $\begin{array}{l}\text { Reimbursement of travel costs or } \\
\text { travel allowance }\end{array}$ & $\begin{array}{r}8.5 \% \\
(\text { firms' } n=59)\end{array}$ & $\begin{array}{r}10.4 \% \\
(\text { firms' } n=48)\end{array}$ & Not available \\
\hline Training & $\begin{array}{r}\text { Total \% (latest } \\
\text { year) }\end{array}$ & $\begin{array}{r}\text { Valid \% (latest } \\
\text { year) }\end{array}$ & $\%(2015)^{a 4}$ \\
\hline
\end{tabular}




\begin{tabular}{|l|r|r|r|}
\hline $\begin{array}{l}\text { Firms reporting to provide } \\
\text { training } \neq\end{array}$ & $\begin{array}{r}83.1 \% \\
\text { (firms' } n=59)\end{array}$ & $\begin{array}{r}96.0 \% \\
\text { (firms' } \mathrm{n}=51 \text { ) }\end{array}$ & $\mathbf{8 2 . 7 \%}$ \\
\hline & & & \\
\hline Time compensation in case of overtime & Total \% & Valid \% & $\%^{d}$ \\
\hline $\begin{array}{l}\text { Firms reporting time } \\
\text { compensation * }\end{array}$ & $\begin{array}{r}64.4 \% \\
\text { (firms' } n=59)\end{array}$ & $\begin{array}{r}80.9 \% \\
\text { (firms' } n=47)\end{array}$ & $92.8 \%$ \\
\hline
\end{tabular}

Missing information: 1) based on information from 50 firms; 2) on 45 firms.

Marked in bold: Information highlighted in the description of results.

\# Information extracted from an open-ended question.

*In this category response we have not included those ECG firms only offering an economic compensation for overtime $(n=5)$ or not incurring overtime $(\mathrm{n}=3)$.

DATA SOURCES: Information about ECG firms has been extracted from Common Good Reports. Latest year available. Information regarding firms in Austria and Germany has been obtained from: a3) Year 2015, Eurostat [trng_cvt_34s] (Eurostat, 2018b), b2) Year 2015, OECD [LFS - FTPT Employment Common] (OECD, 2018a), c) Year 2015, International Labour Office [Global Wage Report 2016/2017] (International Labour Office, 2016), a4) Year 2015, Eurostat [trng_cvt_01s] (Eurostat, 2018c), and d) Year 2013, 3rd European Company Survey (Eurofound, 2015).

Regarding the dimension of information and worker participation (see Table 5), in most of the ECG firms some critical information is disclosed to all workers, mainly referring to financial and operational information, whereas aspects such as salaries or tasks-related descriptions (protocols, job descriptions, etc.) are shared less often. With regard to worker participation schemes, data from the $3^{\text {rd }}$ European Company Survey show that direct participation practices are more prevalent than forms of representative participation in the default economy of Austria and Germany. The picture for ECG firms has a similar pattern but its scope is less clear as there is remarkable variation in the frequency of the existence of participation schemes in ECG firms based on the total or valid percentage (considering the valid percentage, participation schemes are extensive in ECG firms whereas, based on the total percentage, participation schemes are much less prevalent).

Information on worker participation in occupational health might be not complete, as this topic is not directly asked in Common Good Balances and taken from the section describing health promotion measures. Among the organisations mentioning worker participation in this field, it can be observed that whenever works councils are present, forms of representative participation in health tend to exist as well (either health and safety representatives or health and safety committees) whereas only one organisation alluded to a form of direct participation in health: health circles. Financial participation -captured as organisations reporting that employees are shareholders- is present in less than $20 \%$ of ECG firms and leadership legitimacy practices in less than $50 \%$. Among those organisations reporting some kind of democratic processes in the election of managers, only six facilitate full participatory practices while the remaining firms describe election processes with some participatory restrictions (for instance, by engaging workers to a level of consultation but not giving them voice in the final decision, by limiting workers' capacity of decision to some management positions, or by only allowing to participate a share of workers). 
Table 5. Job quality in Economy for the Common Good (ECG) firms compared to the totality of firms in Austria and Germany: information and worker participation

\begin{tabular}{|c|c|c|c|}
\hline \multirow[b]{2}{*}{ Critical information shared with employees } & \multicolumn{2}{|c|}{ Economy for the Common Good firms } & \multirow{2}{*}{$\begin{array}{r}\text { Firms in Austria and Germany } \\
\%\end{array}$} \\
\hline & Total \% & Valid \% & \\
\hline $\begin{array}{l}\text { Firms reporting to provide } \\
\text { critical information } \neq\end{array}$ & $\begin{array}{r}81.4 \% \\
\text { (firms' } n=59 \text { ) }\end{array}$ & $\begin{array}{r}84.2 \% \\
\text { (firms' } n=57 \text { ) }\end{array}$ & Not available \\
\hline Leadership legitimacy & Total \% & Valid \% & $\%$ \\
\hline $\begin{array}{l}\text { Firms reporting processes of } \\
\text { democratic election of managers } \\
\text { by all or part of employees ₹ }\end{array}$ & $\begin{array}{r}32.2 \% \\
\text { (firms' } n=59 \text { ) }\end{array}$ & $\begin{array}{r}41.3 \% \\
(\text { firms' } n=46 \text { ) }\end{array}$ & Not available \\
\hline Direct participation & Total \% & Valid \% & $\%^{d}$ \\
\hline $\begin{array}{l}\text { Firms reporting regular } \\
\text { meetings between employees } \\
\text { and immediate manager } \neq\end{array}$ & $\begin{array}{r}40.7 \% \\
\text { (firms' } n=59 \text { ) }\end{array}$ & $\begin{array}{r}100 \% \\
(\text { firms' } n=24)\end{array}$ & $91.0 \%$ \\
\hline $\begin{array}{l}\text { Firms reporting regular staff } \\
\text { meetings open to all workers at } \\
\text { the establishment } \neq\end{array}$ & $\begin{array}{r}49.2 \% \\
\text { (firms' } n=59 \text { ) }\end{array}$ & $\begin{array}{r}100 \% \\
\text { (firms' } n=29 \text { ) }\end{array}$ & $58.4 \%$ \\
\hline $\begin{array}{l}\text { Firms reporting to undertake } \\
\text { employee surveys }\end{array}$ & $\begin{array}{r}25.4 \% \\
\text { (firms' } n=59 \text { ) }\end{array}$ & $\begin{array}{r}93.8 \% \\
\text { (firms' } n=16 \text { ) }\end{array}$ & $53.1 \%$ \\
\hline Representative participation & Total \% & Valid \% & $\%^{d}$ \\
\hline Firms reporting works councils ₹ & $\begin{array}{r}28.8 \% \\
\text { (firms' } n=59 \text { ) }\end{array}$ & $\begin{array}{r}73.9 \% \\
\text { (firms' } n=23 \text { ) }\end{array}$ & $18.7 \%$ \\
\hline \multicolumn{4}{|l|}{ Worker participation in health and safety } \\
\hline $\begin{array}{l}\text { Firms reporting worker } \\
\text { representation in health and safety } \neq\end{array}$ & $\begin{array}{r}23.7 \% \\
(\text { firms' } n=59)\end{array}$ & $\begin{array}{r}93.3 \% \\
\text { (firms' } n=15 \text { ) }\end{array}$ & Not available \\
\hline \multicolumn{4}{|l|}{ Co-ownership } \\
\hline $\begin{array}{l}\text { Firms reporting that employees } \\
\text { are shareholders } \neq\end{array}$ & $\begin{array}{r}11.9 \% \\
(\text { firms' } n=59)\end{array}$ & $\begin{array}{r}17.1 \% \\
\text { (firms' } n=41 \text { ) }\end{array}$ & Not available \\
\hline
\end{tabular}

Marked in bold: Information highlighted in the description of results.

\# Information extracted from an open-ended question.

DATA SOURCES: Information about ECG firms has been extracted from Common Good Reports, latest available year. Information regarding firms in Austria and Germany has been obtained from: d) Year 2013, 3rd European Company Survey (Eurofound, 2015). 
Finally, Table 6 provides a few indicators concerning psychosocial working conditions, mainly related to workers' ability to have control over the way they work. The same pattern is observed in both in the ECG firms analysed in the study and the Austrian and German economy as a whole: about half of the firms allow (at least part of their) employees to have some control over their tasks and even fewer allow employees to choose their working times. Analysed from the workers' perspective, less than one third have the possibility to work from home. However, for each and every indicator analysed, ECG firms' percentages (total and valid) are greater than those informing about the Austrian and German default economies.

\section{Table 6. Job quality in Economy for the Common Good (ECG) firms compared to the totality of firms in Austria and Germany: home office and control}

\begin{tabular}{|c|c|c|c|}
\hline & \multicolumn{2}{|c|}{ Economy for the Common Good firms } & Firms in Austria and \\
\hline Possibility of home office & Total \% & Valid \% & $\%$ a5 \\
\hline $\begin{array}{l}\text { Share of workers with } \\
\text { possibility of home office } \neq \text { * }\end{array}$ & $\begin{array}{r}\mathbf{2 5 . 8 \%} \text { (employees' } n= \\
13,396)\end{array}$ & $\begin{array}{r}\mathbf{3 1 . 0 \%} \text { (employees' } n= \\
11,122)^{1}\end{array}$ & $16.7 \%$ \\
\hline Control & Total \% (latest year) & Valid \% (latest year) & $\%^{d}$ \\
\hline $\begin{array}{l}\text { Firms reporting that employees } \\
\text { have control over their daily } \\
\text { working time } \neq^{* \star}\end{array}$ & $\begin{array}{r}45.8 \% \\
(\text { firms' } n=59)\end{array}$ & $\begin{array}{r}48.2 \% \\
(\text { firms' } n=56)\end{array}$ & $30.6 \%$ \\
\hline $\begin{array}{l}\text { Firms reporting that employees } \\
\text { can decide on the planning and } \\
\text { execution of their daily work tasks } \ddagger^{* * *}\end{array}$ & $\begin{array}{r}\mathbf{5 9 . 3 \%} \\
(\text { firms' } n=59)\end{array}$ & $\begin{array}{r}94.6 \% \\
(\text { firms' } n=37 \text { ) }\end{array}$ & $61.9 \%$ \\
\hline
\end{tabular}

Missing information: 1) based on information from 25 firms. Marked in bold: Information highlighted in the description of results. \# Information extracted from an open-ended question.

"With respect to ECG firms, the response category "Yes" is referred to employees working in firms providing the possibility of home office to all workers. Eurostat data inform about employed persons who can work from home usually or sometimes.

${ }^{* *}$ In the case of ECG firms, this variable informs about whether workers can determine how their working hours are distributed. In the European Company Survey the variable informs about whether workers have the possibility to adapt the time when they begin or finish their daily work.

*** Regarding ECG firms, the response category "Yes" includes firms in which determination over daily tasks is allowed to all workers or to some workers. In the European Company Survey, the question inquired about who decides on the planning and execution of the daily work tasks. In the present analyses, "Yes" comprises "The employee undertaking the tasks" plus "Both employees and managers or supervisors".

DATA SOURCES: Information about ECG firms has been extracted from Common Good Reports, latest year available. Information regarding firms in Austria and Germany has been obtained from: a5) Year 2016, Eurostat [lfsa_ehomp] (Eurostat, 2019a), and d) Year 2013, 3rd European Company Survey (Eurofound, 2015). 


\section{Discussion and conclusions}

In this paper we approached the work-related characteristics in firms following the ECG principles in Austria and Germany. We first explored the general structure of ECG firms in these countries, also showing data about the situation in their respective economies. ECG firms account for a very small share of the total employment in Austria and Germany $(0.03 \%)$ and they are mostly clustered in a few economic branches that are markedly different from the overall employees' distribution in Austria and Germany. Research on firms' motives to embark on the ECG's model stresses the importance played by social and pro-environment protection goals (Stumpf \& Sommer, 2019), such as in the heterogeneous social economy sector (or third sector) of Germany and Austria (Birkhölzer, 2015; Schneider \& Maier, 2013).

As for job working and employment conditions, we established the three main dimensions of job quality in the ECG model, namely employment quality, information and worker participation, and provision of meaningful work (for instance, facilitating influence over tasks and working time, quality of leadership, or task clarity). Our findings on the implemented work-related managerial practices implemented -or at least, reported- in ECG firms show a prominence of features linked with worker participation and possibilities to determine working hours and tasks. Indeed, "workplace democracy and self-management" is one of the principles signalled in the Human Resource Management literature as one of the main characteristic features of economic movements such as the ECG (Aust, Matthews, \& Muller-Camen, 2019: 5-6). For instance, in the organisations we analysed, and despite the lack of data sources to use as a comparative reference, disclosure of critical information seems to be quite prevalent. The same is true for leadership legitimacy practices (although to a lower extent). With regard to participation schemes, there are more ECG firms reporting the existence of consultative direct participation practices than representative participation forms. When compared to the overall Austrian and German economy, ECG firms stand out for their higher prevalence of works councils. Results regarding direct participation are somewhat equivocal given the difference between the total and valid frequencies. Although the fact of using information reported by management about participative practices at the workplace can lead to the risk of overestimation, this can be lowered if undertaking a documentary revision during the data gathering (for an example regarding worker representation in occupational health, see Fondevila-McDonald et al. (2019)). In this regard, as the Common Good Reports analysed have gone through a process of peer-review or external audit during their production, we deem it reliable when reporting to have forms of worker participation but we cannot assess firms which did not provide information in their reports. 
In general, our data are in line with the findings on work-related characteristics in the social economy sector. On the positive side, our data shows that ECG firms provide more favourable conditions in terms of control and training, which confirms findings observed in France (Richez-Battesti, Petrella, \& Melnik, 2011) and on the non-profit sector in Europe (Ariza-Montes \& Lucia-Casademunt, 2016). The aforementioned studies have also shown that workers in the social economy have a better worklife balance. Our study, unfortunately, does not include any information directly related to work-life balance. We, however, were able to show that the possibility to work at home is very common in ECG firms. On the negative side, part-time work prevails in ECG firms, coinciding with evidence on contractual arrangements in the social economy sector (Ariza-Montes \& Lucia-Casademunt, 2016; Bailly, Chapelle, \& Prouteau, 2012; Richez-Battesti et al., 2011). Nonetheless, assessing part-time in ECG firms in a negative manner -especially if voluntary- is problematic as the ECG model promotes the reduction of the average working hours in order to facilitate citizen engagement and participation, reduce unemployment, and improve work-life balance (Felber \& Hagelberg, 2017). Rather than the existence of part-time work in ECG firms, it is thus more important to determine if this occurs on a voluntary basis or not, which is unfortunately not captured in the analysed data.

Regarding salaries, it has been shown that wages are lower in the social economy, especially in comparison to those in the public sector (Bailly et al., 2012; Richez-Battesti et al., 2011). With respect to ECG firms, only a few firms provided information on salaries in the Common Good Reports. Our findings thus need to be interpreted cautiously. What we did find is that at least almost half of ECG firms provide full-time salaries higher than or equal to the reference value for "living wages" in Austria and Germany. Our analysis reveals that the mean wage inequality between the highest and the lowest income in ECG is 1:3.8. This ratio is below the maximum earning spread advocated by the model (Blachfellner et al., 2017: 42) but slightly greater than in the whole Austrian and German economy. This is an unexpected result as it fits neither with the major interest of the ECG model to limit income inequality (Felber \& Hagelberg, 2017) nor with previous research about wage equity in the non-profit sector (Leete, 2000). Arguably, this result needs to be further analysed since a direct comparison between ECG firms and the overall Austrian and German economy might be concealing key explanatory factors. In addition to the fact that in our sample ECG firms are mostly for-profit organisations and the diverging distribution by economic branches, it is important to stress the higher share of medium and large firms in the ECG model than in the overall economy of Austria and Germany given that there is a positive relationship between firm size and inequality (International Labour Office, 2016). In our study, when analysing the distribution of wage spread ratio by firm size (results not shown), full equality is only present in ECG firms with 5 to 9 workers whereas high wage spread, mostly in medium and large firms. 


\section{Strengths and limitations}

ECG constitutes an alternative economic model of which there is still limited scientific knowledge. Thus, the main strength of our study is to provide the first detailed analysis of the structure of the companies and job quality in firms following the ECG's work-related criteria. However, this study is not without limitations. One constraint is related to the Common Good Reports as a source of information: the breadth and depth of the information varies across companies and indicators, and they provide only limited information on job quality aspects promoted by the ECG (e.g., regarding different forms of contractual arrangements, working hours, earnings, and psychosocial working conditions such as autonomy, task clarity and variety, or justice and quality of leadership, among others). Also, the Common Good Reports allow to characterise job quality only from an organisational perspective. On the plus side, we consider peer-reviewed and externally audited Common Good Reports to be a reliable data source as they have undergone cross-check processes.

Despite the fact that the study has a descriptive nature and that data for the Austrian and German economy as a whole are presented as benchmarks, a few comparability issues have to be considered. Some variables have not been formulated in the same way (e.g. home-office or questions related to control). Further, the sources differ slightly in their study population. As for ECG firms, we restricted our analyses to firms with at least 5 employees whereas the variables on the general structure of the Austrian and German economy, part-time employment and home-office (Eurostat, 2018a, 2019a, 2019a; OECD, 2018b) reported on all companies or employees. The remaining data sources draw information from surveys of firms with 10 or more workers (Eurofound, 2013; Eurostat, 2018b, 2018c; International Labour Office, 2016: 111-112).

Carrying out the exercise of searching for data concerning the overall economy of Germany and Austria also brought to light the difficulty in finding suitable information for some of the study sections involving information of a more "qualitative" nature (for instance, information and worker participation). In some cases, we had to resort to sources such as surveys while in others we were not able to find an appropriate data source. All of this underscores the lack of transparency of "regular" firms with respect to the disclosure of non-financial information. Arguably, most of the data included in this study refer to 2015, before the entry into force of the Directive 2014/95/EU which made non-financial reporting compulsory for large firms as of fiscal year 2017. In any case, the ECG and the social economy in general have been leading the way in the publication of information of this type (Salathé-Beaulieu et al., 2019). The fact that the ECG has a reporting tool that meets the requirements of the non-financial reporting Directive (Hofielen et al., 2017) also provides a significant added value to the ECG and its Common Good Balance sheets. 


\section{Conclusions}

The article explores for the first time job quality in ECG firms in Austria and Germany and provides a picture of the situation of working and employment conditions in these firms with respect to those promoted by the model. Our results suggest that elements of good quality of work in ECG firms are more concentrated in the domains of worker participation and control over working hours and tasks than in pecuniary aspects of employment quality (wages, financial participation, and part-time employment, if on an involuntary basis). Whenever possible we have also presented information for the overall Austrian and German economies. Yet, for a more thorough exploration of job quality components in ECG firms as well as its association with worker outcomes, further analyses should use worker-based responses and compare results from ECG matching workers in other types of companies using, for instance, propensity score matching.

\section{Acknowledgments}

This project has received financial support by the Austrian Science Fund (FWF): M 2158 -G27 Meitner-Programm grant.

\section{References}

ARIZA-MONTES, A. \& LUCIA-CASADEMUNT, A.M. (2016): "Nonprofit Versus For-Profit Organizations: A European Overview of Employees' Work Conditions", Human Service Organizations: Management, Leadership \& Governance, 40(4), 334-351. DOI: 10.1080/23303131.2015.1134742.

AUST, I., MATTHEWS, B. \& MULLER-CAMEN, M. (2019): "Common Good HRM: A paradigm shift in Sustainable HRM?", Human Resource Management Review. DOI: 10.1016/j.hrmr.2019.100705.

BAILLY, F., CHAPELLE, K. \& PROUTEAU, L. (2012): "La qualité de l'emploi dans L'ESS: Etude exploratoire sur la région des Pays de la Loire", Revue internationale de l'économie sociale : Recma, 323, 44-63. DOI:10.7202/1018344ar.

BIRKHÖLZER, K. (2015): Social Enterprises Models in Germany (ICSEM Working Papers No. 15; p. 28). Liege: The International Comparative Social Enterprise Models (ICSEM) Project. 
BLACHFELLNER, M., DROSG-PLÖCKINGER, A., FIEBER, S., HOFIELEN, G., KNAKRÜGGE, L., KOFRANEK, M., ... TERI, M. (2017): Workbook compact balance sheet 5.0. Retrieved from Matrix Development Team website: https://www.ecogood.org/media/filer_public/5d/4d/5d4d17bc-156b-44ec-9115-fe6b37c63187/ecg_compact_balance_sheet_workbook.pdf.

BURCHELL, B., SEHNBRUCH, K., PIASNA, A. \& AGLONI, N. (2014): "The quality of employment and decent work: Definitions, methodologies, and ongoing debates", Cambridge Journal of Economics, 38, 459-477. DOI:10.1093/cje/bet067.

CAMPOS, V., SANCHIS, J.R. \& EJARQUE, A. (2019): "El modelo de la Economía del Bien Común. Un estudio empírico sobre su aplicación a la empresa privada", REVESCO, Revista de Estudios Cooperativos, 132, 46-76. DOI: 10.5209/REVE.64304.

CHAVES, R. \& MONZÓN, J.L. (2018): "La economía social ante los paradigmas económicos emergentes: Innovación social, economía colaborativa, economía circular, responsabilidad social empresarial, economía del bien común, empresa social y economía solidaria", CIRIEC-España, Revista de Economía Pública, Social y Cooperativa, 93, 5-50. DOI: 10.7203/CIRIEC-E.93.12901.

ECONOMY FOR THE COMMON GOOD (2015): Handbook-ECG - Balance Website. Retrieved February 20, 2019, from https://balance.ecogood.org/matrix-4-1-en/guidelines.

ECONOMY FOR THE COMMON GOOD (2017): Common Good Matrix. Retrieved May 5, 2020, from https://www.ecogood.org/en/our-work/common-good-balance-sheet/common-good-matrix/.

ECONOMY FOR THE COMMON GOOD (2019): ECG businesses and organisations. Retrieved February 14, 2019, from https://www.ecogood.org/en/movement/ecg-businesses-and-organisations/.

EUROFOUND (2013): European Company Survey 2013 I Eurofound. Retrieved February 15, from https://www.eurofound.europa.eu/surveys/european-company-surveys/european-company-survey-2013.

EUROFOUND (2015): European Company Survey, 2013 [data collection]. Colchester: UK Data Service, $\mathrm{SN}$.

EUROPEAN ECONOMIC AND SOCIAL COMMITTEE (2015): Opinion of the Economic and Social Committee on 'The Economy for the Common Good: A sustainable economic model geared towards social cohesion' (own-initiative opinion), EUR-Lex-52015IE2060-EN - EUR-Lex $\S$ (2015).

EUROSTAT (2018a): Annual enterprise statistics by size class for special aggregates of activities (NACE Rev. 2). Retrieved February 13, 2019, from http://appsso.eurostat.ec.europa.eu/nui/show. do?dataset=sbs_sc_sca_r2\&lang=en.

EUROSTAT (2018b): Enterprises employing IVT participants by size class. Retrieved February 14, 2019, from http://appsso.eurostat.ec.europa.eu/nui/show.do?dataset=trng_cvt_34s\&lang=en 
EUROSTAT (2018c): Enterprises providing training by type of training and size class - $\%$ of all enterprises. Retrieved February 18, 2019, from http://appsso.eurostat.ec.europa.eu/nui/show.do?dataset=trng_cvt_01s\&lang=en.

EUROSTAT (2019a): Employed persons working from home as a percentage of the total employment, by sex, age and professional status (\%. Retrieved February 18, 2019, from http://appsso.eurostat. ec.europa.eu/nui/show.do?dataset=Ifsa_ehomp\&lang=en.

EUROSTAT (2019b): Employees by sex, age and occupation (1000). Retrieved February 18, 2019, from http://appsso.eurostat.ec.europa.eu/nui/show.do?dataset=lfsq_eegais\&lang=en.

FELBER, C. (2012): La economía del bien común: Un modelo económico que supera la dicotomía entre capitalismo y comunismo para maximizar el bienestar de nuestra sociedad, Barcelona: Ediciones Deusto.

FELBER, C. \& HAGELBERG, G. (2017): The Economy for Common Good. A workable, transformative ethics-based alternative, Washington: The next system project.

FELBER, C., CAMPOS, V. \& SANCHIS, J.R. (2019): "The Common Good Balance Sheet, an Adequate Tool to Capture Non-Financials?", Sustainability, 11(14), 3791. DOI:10.3390/su11143791.

FONDEVILA-MCDONALD, Y., MOLINERO-RUIZ, E., VERGARA-DUARTE, M., GUILLÉN, M., OLLÉ-ESPLUGA, L., MENÉNDEZ, M. \& BENACH, J. (2019): "Is There an Estimation Bias in Occupational Health and Safety Surveys? The Mode of Administration and Informants as a Source of Error", Sociological Methods \& Research, 48, 185-201. DOI:10.1177/0049124116672681.

GEMEINWOHL ÖKONOMIE (2018): GWOe-Berichte-ECG - Balance Website. Retrieved January 21, 2018, from http://balance.ecogood.org/gwoe-berichte.

GEMEINWOHL ÖKONOMIE (2018): "GWOe Liste externe Audit Peer Evaluierung-Excel". Retrieved January 21, from https://balance.ecogood.org/gwoe-berichte/gwoe-liste-externe-audit-peer-evaluierung.xlsx/view.

GÓMEZ CALVO, V. \& GÓMEZ-ÁLVAREZ DÍAZ, R. (2016): "La economía del bien común y la economía social y solidaria, ¿son teorías complementarias?", CIRIEC-España, Revista de Economía Pública, Social y Cooperativa, 87, 257-294.

GÓMEZ-ÁLVAREZ, R., MORALES, R. \& RODRÍGUEZ, C. (2017): "La Economía del Bien Común en el ámbito local", CIRIEC-España, Revista de Economía Pública, Social y Cooperativa, 90, 189222. DOI: 10.7203/CIRIEC-E.90.

HOFIELEN, G., RESCH, R. \& BEHM, A. (2017): "Die Gemeinwohl-Bilanz 5.0 als Berichtsrahmen Für Nichtfinanzielle Erklärungenim Sinne Des CSR-Richtlinie-Umsetzungsgesetzes Vom 11.04.17". Retrieved May 7, 2020, from https://hm-practices.org/wp-content/uploads/2017/09/CSR-UmsetzungsG-Dtl.-und-GW-Bilanz_Juli-2017_final.pdf.

HOLMAN, D. (2013): "Job types and job quality in Europe", Human Relations, 66, 475-502. DOI:10.1177/0018726712456407. 
INTERNATIONAL LABOUR OFFICE (2016): Global Wage Report 2016/17: Wage inequality in the workplace. Geneva: ILO.

KÜHN, C. (2020): Nachhaltige Entwicklung von unten? Die Gemeinwohl-Ökonomie zwischen utopischen Visionen, zivilgesellschaftlichen Initiativen und basisdemokratischen Entscheidungen. Retrieved May 4, 2020, from https://www.euroethno.hu-berlin.de/de/forschung/projekte/nachhaltige-entwicklung-von-unten.

LEETE, L. (2000): "Wage equity and employee motivation in nonprofit and for-profit organizations", Journal of Economic Behavior \& Organization, 43(4), 423-446.

MULLER-CAMEN, M. \& CAMEN, J. (2018): "Economy for the Common Good: Sonnentor". In: Palgrave Studies in Sustainable Business In Association with Future Earth. Progressive Business Models, 123-142. DOI: 10.1007/978-3-319-58804-9_6.

OECD (2018a): FTPT employment based on a common definition. Retrieved February 18, 2019, from https://stats.oecd.org/Index.aspx?DataSetCode=LFS_SEXAGE_I_R

OECD (2018b): STAN Industrial Analysis. Retrieved February 18, 2019, from https://stats.oecd.org/ Index.aspx?DataSetCode=STANI4_2016.

RICHEZ-BATTESTI, N., PETRELLA, F. \& MELNIK, E. (2011): "Quelle qualité de l'emploi au sein de l'économie sociale et solidaire?: Premiers résultats sur données françaises", Revue internationale de l'économie sociale: Recma, 319, 57-77. DOI:10.7202/1020807ar.

SALATHÉ-BEAULIEU, G., BOUCHARD, M.J. \& MENDELL, M. (2019): Sustainable Development Impact Indicators for Social and Solidarity Economy: State of the Art, Geneva: United Nations Research Institute for Social Development (UNRISD).

SANCHIS, J.R., CAMPOS, V. \& EJARQUE, A. (2019): Economy for the Common Good Model. Statistical validation of its metrics and impacts in the business sphere, València: Chair in Economy for the Common Good.

SANCHIS, J.R. \& CAMPOS, V. (2018): "Economía Del Bien Común y Finanzas Éticas", CIRIEC-ESpaña, Revista de Economía Pública, Social y Cooperativa, 93, 241-64. DOI: 10.7203/CIRIEC-E.93.11012.

SCHNEIDER, H. \& MAIER, F. (2013): Social Entrepreneurship in Österreich. Retrieved from Wirtschaftsuniversität Wien website: http://epub.wu.ac.at/4061/1/se_in_austria.pdf.

STUMPF, K. \& SOMMER, B. (2019): "The Economy for the Common Good: A European countermovement against the destructive impacts of laissez-faire capitalism?", Culture, Practice and Europeanization, 4, 103-115.

WARHURST, C., WRIGHT, S. \& LYONETTE, C. (2017): Understanding and measuring job quality: Part 1-Thematic Literature Review, London: CIPD. 